DOI: 10.15290/aipan.2020.11

\title{
Osoby z niepełnosprawnością sprzężoną i ze spektrum autyzmu w środowiskowych domach samopomocy - próba oceny istniejących rozwiązań normatywnych
}

\author{
Maciej Borski \\ Wyższa Szkoła Humanitas w Sosnowcu \\ maciej.borski@humanitas.edu.pl \\ ORCID: https://orcid.org/0000-0001-8210-7968
}

\section{Zagadnienia wprowadzające}

Zasadniczym celem tego opracowania jest próba ukazania wsparcia, jakiego państwo udziela szczególnej kategorii osób z zaburzeniami psychicznymi - osobom ze spektrum autyzmu i z niepełnosprawnością sprzężoną - oraz ich opiekunom, umożliwiając im skorzystanie z oferty środowiskowych domów samopomocy (ŚDS). Ze względu na ograniczone ramy tego rozdziału chciałbym skupić się przede wszystkim na kwestii finansowania ŚDS, analizując rozwiązania prawne, jakie prawodawca wprowadza sukcesywnie od lipca 2017 r., chcąc zwiększyć udział w tych placówkach osób z niepełnosprawnością sprzężoną i ze spektrum autyzmu. Bazując na konkretnych regulacjach normatywnych, podejmę próbę odpowiedzi na pytanie, dlaczego mimo konkretnych rozwiązań ukierunkowanych na ww. grupę osób nie udało się w praktyce doprowadzić do znaczącego zwiększenia uczestnictwa tych osób w zajęciach realizowanych w ramach ŚDS.

Środowiskowe domy samopomocy to ośrodki wsparcia dla dorosłych osób z zaburzeniami psychicznymi, czyli dla osób chorych psychicznie i niepełnosprawnych intelektualnie (upośledzonych umysłowo). Zapewniają one dla swoich uczestników pobyt dzienny lub całodobowy. Prowadzone są przez jednostki samorządu terytorialnego jako zadanie zlecone $\mathrm{z}$ zakresu administracji rządowej, finansowane są natomiast $\mathrm{z}$ budżetu wojewody. 
Należy pamiętać, że pod pojęciem „osoba z zaburzeniami psychicznymi” ${ }^{1}$ kryją się trzy odrębne grupy uczestniczące w zajęciach ŚDS. Są to osoby: chore psychicznie (wykazujące zaburzenia psychotyczne), osoby upośledzone umysłowo (niepełnosprawne intelektualnie), osoby wykazujące inne zakłócenia czynności psychicznych, które zgodnie ze stanem wiedzy medycznej zaliczane są do zaburzeń psychicznych i wymagają świadczeń zdrowotnych lub innych form pomocy i opieki niezbędnych do życia w środowisku rodzinnym lub społecznym. Każda $\mathrm{z}$ tych grup potrzebuje innych form pomocy środowiskowej, leczenia i metod terapii. Dlatego też placówki te dzielą się na:

- ŚDS, przeznaczone dla osób przewlekle psychicznie chorych (typ A),

- ŚDS, przeznaczone dla osób upośledzonych umysłowo (typ B),

- ŚDS, przeznaczone dla osób wykazujących inne przewlekłe zaburzenia czynności psychicznych (typ C) i od ostatniej nowelizacji, która weszła w życie 5 czerwca 2019 r.,

- ŚDS, przeznaczone dla osób ze spektrum autyzmu lub niepełnosprawnościami sprzężonymi (typ D).

Podstawowym zadaniem domów jest przede wszystkim podtrzymywanie i rozwijanie w uczestnikach umiejętności niezbędnych do możliwie najbardziej samodzielnego życia. Placówki ŚDS świadczą usługi dostosowane do szczególnych potrzeb osób z zaburzeniami psychicznymi, w szczególności: pracę socjalną, psychoterapię, rehabilitację leczniczą, społeczną i zawodową, usprawnienie, organizację czasu wolnego. Specyfika środowiskowych domów polega na tym, że stanowią one oparcie dla rehabilitacji psychiatrycznej w środowisku, proponując konkretne programy rehabilitacyjne.

Środowiskowe domy samopomocy działają:

- w strukturach ośrodków pomocy społecznej,

- jako samodzielne jednostki organizacyjne,

- jako placówki prowadzone przez organizacje pozarządowe.

Okres korzystania $\mathrm{z}$ miejsca całodobowego pobytu $\mathrm{w}$ środowiskowym domu samopomocy nie może być jednorazowo dłuższy niż 3 miesiące, z możliwością przedłużenia do 6 miesięcy w uzasadnionych przypadkach, przy czym maksymalny okres pobytu całodobowego osoby w roku kalendarzowym nie może być dłuższy niż 8 miesięcy. 


\section{Podstawowe regulacje dotyczące finansowania ŚDS}

Utrzymanie ŚDS wymaga stałego finansowania. Generalnie bieżące funkcjonowanie ŚDS finansowane jest $\mathrm{z}$ budżetu państwa. Zgodnie $\mathrm{z}$ art. 51c ust. 2 ustawy o pomocy społecznej ${ }^{2}$ miesięczną kwotę dotacji z budżetu państwa na pokrycie bieżących kosztów prowadzenia ośrodków wsparcia dla osób z zaburzeniami psychicznymi ustala wojewoda - jako iloczyn aktualnej liczby osób korzystających $\mathrm{z}$ usług $\mathrm{w}$ tych ośrodkach oraz średniej miesięcznej wojewódzkiej kwoty dotacji na jednego uczestnika, nie wyższą jednak niż średnia miesięczna kwota dotacji wyliczona dla województwa. Niezależnie od powyższego osoba przyjęta do ŚDS lub jej opiekun zobowiązani są do ponoszenia odpłatności miesięcznej za usługi świadczone w ŚDS, a zatem do ich współfinansowania. Odpłatność ta ustalana jest na zasadach określonych w ustawie o pomocy społecznej oraz w oparciu o rozporządzenie właściwego wojewody, corocznie publikowane w Dzienniku Urzędowym właściwego województwa na podstawie art. $51 \mathrm{c}$ ust. 3 ustawy o pomocy społecznej. Zgodnie z art. 51b ust. 1 ustawy o pomocy społecznej odpłatność za usługi wynosi 5\% kwoty dochodu uczestnika samotnie gospodarującego lub kwoty dochodu na osobę w rodzinie, ale tylko w sytuacji, jeżeli dochód uczestnika samotnie gospodarującego lub dochód na osobę w rodzinie przekracza kwotę 300\% odpowiedniego kryterium dochodowego, tj. w przypadku uczestnika samotnie gospodarującego, gdy jego dochód przekracza kwotę 1902 zł, a w przypadku uczestnika zamieszkującego w rodzinie, gdy dochód na osobę w rodzinie przekracza kwotę 1542 zł. Z kolei zgodnie $\mathrm{z}$ art. 51b ust. 3 wspomnianej ustawy odpłatność za usługi całodobowe ustala się w wysokości 70\% dochodu osoby korzystającej z usług, proporcjonalnie do okresu jej pobytu. Decyzję o skierowaniu do środowiskowego domu samopomocy i decyzję ustalającą odpłatność za korzystanie z usług w tych ośrodkach wydaje w myśl art. $51 \mathrm{~b}$ ust. 5 ustawy o pomocy społecznej właściwy organ jednostki samorządu terytorialnego, prowadzącej lub zlecającej prowadzenie środowiskowego domu samopomocy, który z kolei na podstawie ust. 6 wyżej wskazanego przepisu może zwolnić te osoby, na ich wniosek, częściowo lub całkowicie z tej odpłatności.

\section{Spektrum autyzmu i niepełnosprawność sprzężona - zagadnienia terminologiczne}

Udzielenie odpowiedzi na sformułowane na wstępie pytanie wymaga dokonania podstawowych ustaleń terminologicznych. W szczególności konieczne jest ustalenie beneficjentów wsparcia udzielanego przez państwo osobom z zaburzenia- 
mi psychicznymi, czyli jego zakresu podmiotowego poprzez wyjaśnienie, kim jest osoba ze spektrum autyzmu i osoba $\mathrm{z}$ niepełnosprawnością sprzężoną.

Osoby ze spektrum autyzmu (ASD - Autism Spectrum Disorders) to szeroka grupa obejmująca różne typy osób o cechach autystycznych, wykazujących odmienne mechanizmy lub przyczyny powodujące trudności rozwojowe i mające często odrębne wymagania wobec środowiska. Wszystkie one charakteryzują się znacznymi zaburzeniami interakcji społecznych i komunikacji, jak również znacznie ograniczonymi zainteresowaniami i bardzo powtarzalnym zachowaniem. Spektrum autyzmu obejmuje następujące przypadłości: autyzm dziecięcy ${ }^{3}$, autyzm atypowy ${ }^{4}$, zespół Aspergera ${ }^{5}$, upośledzenie zdolności niewerbalnego uczenia się $^{6}$, autyzm wysokofunkcjonujący ${ }^{7}$, zaburzenie semantyczno-pragmatyczne ${ }^{8}$, zespół wielu złożonych zaburzeń rozwojowych ${ }^{9}$, hiperleksję $e^{10}$.

Złożone zaburzenie rozwoju i funkcjonowania ośrodkowego układu nerwowego, charakteryzujące się zakłóceniami zdolności komunikowania uczuć i budowania relacji interpersonalnych, zubożeniem i stereotypowością zachowań oraz trudnościami z integracją wrażeń zmysłowych.

Jest to całościowe zaburzenie rozwoju, różniące się od wczesnego autyzmu dziecięcego przede wszystkim późniejszym początkiem występowania objawów (około 3. roku życia lub później).

Zaburzenie to obejmuje przede wszystkim upośledzenie umiejętności społecznych, trudności w akceptowaniu zmian, ograniczoną elastyczność myślenia przy braku upośledzenia umysłowego oraz szczególnie pochłaniające, obsesyjne zainteresowania, natomiast rozwój mowy oraz rozwój poznawczy przebiega bardziej prawidłowo w porównaniu do autyzmu dziecięcego. Głównymi kryteriami odróżniającymi zespół Aspergera od autyzmu głębokiego są brak opóźnienia rozwoju mowy i innych istotnych jej zaburzeń uniemożliwiających logiczną komunikację oraz prawidłowy rozwój poznawczy.

6 Zaburzenie uczenia się (właściwiej wada neurologiczna), przypominająca całościowe zaburzenie rozwoju, mająca podłoże najprawdopodobniej związane z zaburzonym funkcjonowaniem prawej półkuli mózgu lub uszkodzeniem istoty białej.

$7 \quad$ Nieformalne określenie przypadków autyzmu, w których iloraz inteligencji przekracza 90, co sprawia, że osoby nim dotknięte w miarę dobrze funkcjonują w społeczeństwie.

8 Zaburzenie rozwoju psychicznego ze spektrum autyzmu, charakteryzujące się przede wszystkim poważnymi trudnościami w rozumieniu i używaniu mowy (np. nierozumieniem tekstu, przenośni, żartów) oraz opóźnieniem w jej rozwoju. Deficyty w innych dziedzinach, np. zachowaniu, sprawności fizycznej, ale przede wszystkim w kontaktach społecznych, są zwykle mniejsze niż przy zespole Aspergera lub autyzmie dziecięcym.

9 Zaburzenie rozwoju należące do spektrum autyzmu i spektrum schizofrenii, charakteryzujące się wczesnym początkiem (niekiedy w pierwszych latach życia). Powoduje charakterystyczne dla zaburzeń związanych z autyzmem trudności w komunikacji i kontaktach społecznych oraz poważne zaburzenia emocji z nieprawidłowościami w myśleniu. Ma niekorzystny wpływ na inteligencję. Problemy osób z tym zaburzeniem wynikają przede wszystkim z braku kontroli nad emocjami i nadmiernej wyobraźni (w przeciwieństwie do autyzmu), która wywołuje przerażające lęki oraz trudności z odróżnieniem fikcji od rzeczywistości (mogą doprowadzać nawet do stanów psychotycznych). Ludzie ci mogą mieć zarówno nadmierną chęć kontaktów z innymi, jak i też być niezwykle wycofani. W kontaktach tych często brakuje właściwej empatii.

10 Objaw zaobserwowany u dzieci, które charakteryzują się następującymi właściwościami: 1) wcześnie przejawiająca się zdolność do czytania, wykraczająca poza to, czego można się spodziewać od dziecka w jego wieku chronologicznym, albo intensywna fascynacja literami lub cyframi; 2) znaczne trudności w zakresie rozumienia języka werbalnego; 3) nienormalne umiejętności społeczne, trudności w socjalizacji oraz w prawidłowym uczestniczeniu w interakcjach z innymi ludźmi; 4) nieumiejętność nawiązywania kontaktów, niemożność odczytania cudzych intencji i zamiarów. 
Osoby z niepełnosprawnością sprzężoną i ze spektrum autyzmu...

Specyfika poszczególnych przypadłości powoduje, że osoby z niepełnosprawnościami ze spektrum autyzmu wymagają bardzo indywidualnego podejścia. Jak słusznie podkreśla Ewa Pisula, „Nietypowy przebieg rozwoju osób z zaburzeniami należącymi do autystycznego spektrum trudno zamknąć w jednoznacznym opisie"11, obraz analizowanych zaburzeń jest bowiem bardzo różnorodny.

Warto podkreślić, że mimo prowadzonych od wielu lat badań naukowych nie udało się do dziś w sposób jednoznaczny określić przyczyn wywołujących ASD. Czynniki leżące u podłoża odmiennego przebiegu rozwoju osób z zaburzeniami ze spektrum autyzmu pozostają zatem wciąż przedmiotem dyskusji i sporów naukowych. Początkowo największą popularność uzyskało podejście psychoanalityczne, które przyczyn autyzmu upatruje w zaburzonych relacjach rodziców z potomkiem ${ }^{12}$. Chociaż idee te nigdy nie zostały naukowo potwierdzone, a obecnie uważane są za przestarzałe, to jednak - jak słusznie zauważa E. Pisula - wywarły znaczny wpływ na postrzeganie autyzmu i mogą być przyczyną tendencji opinii społecznej do obwiniania rodziców dzieci o ich zaburzenia rozwojowe ${ }^{13}$. Przeprowadzone w ostatnich latach badania opinii społecznej potwierdzają, że ta błędna teoria często powodowała wzajemne obwinianie się rodziców o to, że zaburzenie dziecka jest związane z popełnianymi przez nich błędami wychowawczymi ${ }^{14}$. Dziś autyzm definiuje się jako zaburzenie neurorozwojowe, „w którego etiologii zasadniczą rolę odgrywają mechanizmy neurobiologiczne" 15 . Z kolei według Jacka Błeszyńskiego jest to „zaburzenie w rozwoju manifestujące się niejednorodnym czasem wystąpienia (...) zróżnicowanym przebiegiem i często odmiennie nasiloną symptomatologią w funkcjach komunikacji i zachowaniu"16.

Co prawda autyzm jest zaburzeniem rozwojowym, które trwa całe życie i jest nieuleczalny, jednak odpowiednio wcześnie postawiona diagnoza i dostosowana do indywidualnych potrzeb terapia może znacznie poprawić jakość życia i sposób funkcjonowania osoby $\mathrm{z}$ autyzmem. Nieodłącznym elementem działań mających na celu pomoc takim osobom i ich rodzinom powinno być przeciwdziałanie wykluczeniu społecznemu i dyskryminacji oraz umożliwienie godnej egzystencji $\mathrm{w}$ warunkach odpowiednich do potrzeb. Warto $\mathrm{w}$ tym miejscu podkreślić, że zaburzenia ze spektrum autyzmu należą współcześnie do najczęściej występujących problemów rozwojowych. Potwierdzenie tej tezy znaleźć można m.in. w raporcie Ogólnopolski Spis Autyzmu. Sytuacja młodzieży i dorosłych $z$ autyzmem w Pol-

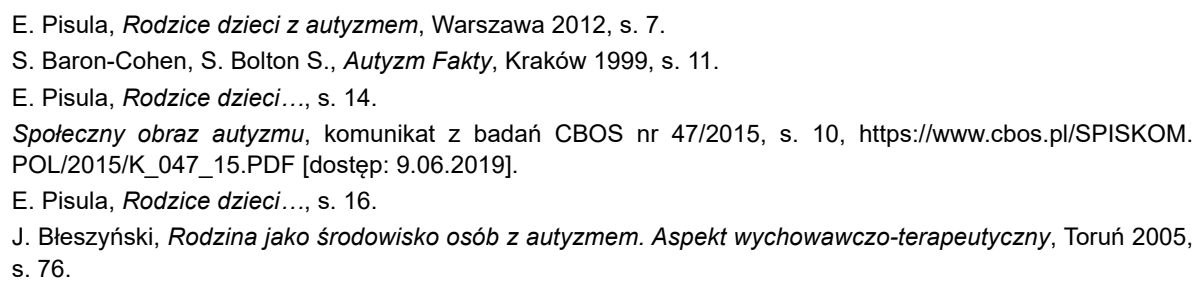


sce, prezentującym wyniki badań zrealizowanych w roku 2016 na grupie dorosłych i dorastających Polaków dotkniętych $\mathrm{ASD}^{17}$. Liczba zdiagnozowanych przypadków autyzmu i zaburzeń z jego spektrum w ostatnich latach wzrosła - według danych szacunkowych w Polsce żyje około 30 tys. osób z autyzmem, w tym około 20 tys. dzieci i 10 tys. dorosłych ${ }^{18}$.

Drugim pojęciem wymagającym wyjaśnienia jest niepełnosprawność sprzężona. Jest ono definiowane nie tylko na gruncie nauk medycznych, ale także socjologicznych i prawnych. Próby zdefiniowania tego zjawiska podejmują także psycholodzy i pedagodzy. Definicję legalną tego pojęcia dostarczają dwa akty normatywne: ustawa Prawo oświatowe ${ }^{19}$ (w art. 4 pkt 32) i ustawa o systemie oświaty ${ }^{20}$ (art. 3 pkt 18), które stanowią, że jako niepełnosprawność sprzężoną należy rozumieć występowanie u dziecka niesłyszącego lub słabosłyszącego, niewidomego lub słabowidzącego, z niepełnosprawnością ruchową, w tym $\mathrm{z}$ afazją, z niepełnosprawnością intelektualną albo $\mathrm{z}$ autyzmem, w tym $\mathrm{z}$ zespołem Aspergera, co najmniej jeszcze jednej z wymienionych niepełnosprawności. Zważywszy na fakt, że definicja ta odnosi się wyłącznie do dzieci i ma zastosowanie jedynie w zakresie systemu edukacji, należałoby podjąć próbę stworzenia pojęcia, które miałoby charakter bardziej uniwersalny. Właśnie dlatego na potrzeby niniejszego opracowania niepełnosprawność sprzężoną traktuję jako występowanie dwóch lub więcej niepełnosprawności u jednej osoby, które wspólnie tworzą „skomplikowaną strukturę”. Jak słusznie zauważa Grzegorz Wiącek, nie można niepełnosprawności sprzężonej traktować tylko jako sumy niepełnosprawności składowych. Podkreśla on przy tym, że termin „niepełnosprawność sprzężona” akcentuje dodatkowo wewnętrzne trudności, skomplikowaną strukturę takiej niepełnosprawności oraz fakt „nierozerwalnej całości dwóch lub więcej jej sprzężonych rodzajów”21.

Za niepełnosprawność sprzężoną mogą odpowiadać przede wszystkim nieprawidłowe chromosomy i patologiczne geny, a ponadto wszelkiego rodzaju wirusy, bakterie, środki chemiczne, promieniowanie oraz urazy mechaniczne. Wiele niepełnosprawności sprzężonych powstaje w okresie prenatalnym, w którym na przykład zapalenie opon mózgowych może wywołać jednocześnie głuchotę oraz upośledzenie umysłowe. Należy także podkreślić, że z jednej strony niepełnosprawność sprzężona może powstać w tym samym czasie, np. wskutek rozległego urazu mózgu

17 Ogólnopolski Spis Autyzmu. Sytuacja młodzieży i dorosłych z autyzmem w Polsce, red. M. Płatos, Warszawa 2016, www.spisautyzmu.pl [dostęp: 14.07.2020].

18 Stowarzyszenie Pomocy Osobom Autystycznym „Dalej Razem”, http://www.autyzm.zgora.pl/pl/id.10004 [dostęp: 14.07.2020].

19 Ustawa z dnia 14 grudnia 2016 r. - Prawo oświatowe (tekst jedn. Dz.U. z 2020 r. poz. 910 z późn. zm.).

20 Ustawa z dnia 7 września 1991 r. o systemie oświaty (tekst jedn. Dz.U. z 2019 r. poz. 1481 z późn. zm.).

21 Por. G. Wiącek, Problem definiowania niepełnosprawności sprzężonej, [w:] Sytuacja i możliwości pomocy dla osób z rzadkimi i sprzężonymi ograniczeniami sprawności, red. A. Brzezińska, R. Kaczan, K. Smoczyńska, Warszawa 2010, s. 73. 
Osoby z niepełnosprawnością sprzężoną i ze spektrum autyzmu...

pojawiają się jednocześnie: afazja, padaczka, głuchota, z drugiej strony wystąpienie poszczególnych niepełnosprawności może być znacznie rozłożone w czasie, np. osoba, która jest niesłysząca od urodzenia na skutek wypadku, może utracić sprawność ruchową. Również schorzenia neurologiczne mogą prowadzić najpierw do utraty sprawności ruchowej, potem do głuchoty, a nawet do inwalidztwa wzroku ${ }^{22}$.

\section{Zmiana zasad finansowania uczestnictwa w ŚDS dla osób ze spektrum autyzmu i z niepełnosprawnością sprzężoną}

Specyfika poszczególnych przypadłości mieszczących się w spektrum autyzmu powoduje, że osoby dotknięte tym rodzajem niepełnosprawności wymagają bardzo indywidualnego podejścia. Co prawda autyzm jest zaburzeniem rozwojowym, które trwa całe życie i jest nieuleczalny, jednak odpowiednio wcześnie postawiona diagnoza i dostosowana do indywidualnych potrzeb terapia może znacznie poprawić jakość ich życia i sposób funkcjonowania. Nieodłącznym elementem działań mających na celu pomoc takim osobom i ich rodzinom powinno być przeciwdziałanie wykluczeniu społecznemu i dyskryminacji oraz umożliwienie godnej egzystencji w warunkach odpowiednich do potrzeb. Dotyczy to oczywiście także osób z niepełnosprawnością sprzężoną, w tym sytuacji, gdy niepełnosprawność ze spektrum autyzmu sprzężona jest $\mathrm{z}$ inną, np. z upośledzeniem umysłowym.

Bardzo istotne jest, aby osoby z niepełnosprawnością sprzężoną oraz ze spektrum autyzmu już od młodych lat poddawane były edukacji i rehabilitacji. Może ona być prowadzona w różnorodnych ośrodkach wsparcia, a także w przedszkolach, szkołach specjalnych, jak również w masowych - w zależności od rodzaju i stopnia zaburzenia. Działania edukacyjno-rehabilitacyjne jako priorytetowe przyjmować powinny edukację ukierunkowaną na naukę samodzielności i samoobsługi, podtrzymywanie i prowadzenie komunikacji z innymi ludźmi, jak również terapię ruchową ${ }^{23}$.

Ważną rolę w zapewnieniu odpowiedniego wsparcia edukacyjnego, opiekuńczego i rehabilitacyjnego tej szczególnej kategorii osób z niepełnosprawnościami pełnią ŚDS. To oczywiście wymaga zapewnienia odpowiednich środków finansowych. Warto w tym kontekście zwrócić uwagę na treść przepisu art. 51c ust. 5 ustawy o pomocy społecznej, wprowadzonego do niej ustawą o zmianie niektórych ustaw

Szerzej na temat pojmowania niepełnosprawności sprzężonej zob. m.in.: J. Doroszewska, Pedagogika specjalna, t. 1-2, Wrocław-Warszawa-Kraków-Gdańsk-Łódź 1989; T. Majewski, Edukacja i rehabilitacja osób głuchoniewidomych, Warszawa 1995; Š. Vašek, A. Stankowski, Zarys pedagogiki specjalnej, Katowice 2006; A. Twardowski, Wychowanie dzieci o niepełnosprawności sprzężonej, [w:] Dziecko niepełnosprawne w rodzinie, red. I. Obuchowska, Warszawa 2008, s. 515-542.

23 Działania te w praktyce można zobaczyć m.in. na profilu facebookowym ŚDS Kamyk - http:/www.facebook. com/sds.kamyk/videos/opieka-terapia-edukacja [dostęp 31.12.2020]. 
w związku z realizacją programu „Za życiem”24. Przepis ten przewiduje, że właściwy wojewoda może zwiększyć do 30\% dotację na jednego uczestnika środowiskowego domu samopomocy, ustalaną na uczestników z niepełnosprawnością sprzężoną lub ze spektrum autyzmu, którzy posiadają orzeczenie o znacznym stopniu niepełnosprawności wraz ze wskazaniem konieczności stałej lub długotrwałej opieki lub pomocy innej osoby w związku ze znacznie ograniczoną możliwością samodzielnej egzystencji.

Przytoczony wyżej przepis stanowi realizację priorytetu 3.2 kompleksowego programu wsparcia dla rodzin "Za życiem” ${ }^{25}$, polegającego na rozwoju sieci ŚDS, w tym rozwoju bazy całodobowej w jednostkach już funkcjonujących i rozszerzeniu typów ŚDS na osoby z niepełnosprawnością sprzężoną oraz o osoby ze spektrum autyzmu. W uzasadnieniu do projektu ustawy projektodawca zwracał uwagę, że środowiskowe domy samopomocy powinny rozszerzyć ofertę dla osób z niepełnosprawnością sprzężoną i ze spektrum autyzmu, które posiadają orzeczenie o znacznym stopniu niepełnosprawności, wraz ze wskazaniem konieczności stałej lub długotrwałej opieki lub pomocy innej osoby w związku ze znacznie ograniczoną możliwością samodzielnej egzystencji. Podkreślano, że osoby z niepełnosprawnością sprzężoną i ze spektrum autyzmu do tej pory często nie znajdowały miejsca w środowiskowych domach samopomocy ${ }^{26}$. Sytuacja ta spowodowana była najczęściej niewystarczającą liczbą kadry przypadającej na jednego uczestnika oraz nieodpowiednim standardem usług i wyposażenia ŚDS. Tymczasem nie ulega wątpliwości, że osoby z niepełnosprawnością sprzężoną lub ze spektrum autyzmu mają znacznie zwiększone w stosunku do innych uczestników ŚDS potrzeby. Aby prowadzona terapia przynosiła właściwy skutek, osoby te wymagają wzmożonego nadzoru i pracy oraz odpowiedniego wyposażenia jednostki, np. w pokój wyciszeń. Ponadto dla tej grupy osób konieczne jest prowadzenie specjalistycznych treningów - np. umiejętności komunikacyjnych.

24 Ustawa z dnia 22 czerwca 2017 r. o zmianie niektórych ustaw w związku z realizacją programu „Za życiem” (Dz.U. z 2017 r. poz. 1292).

25 Program ten - przygotowany przez międzyresortowy zespół powołany przez premier Beatę Szydło - jest rozwinięciem i uzupełnieniem działań podjętych w ramach kontrowersyjnej ustawy o wsparciu kobiet w ciąży i rodzin „Za życiem”, uchwalonej 4 listopada 2016 r., dotyczącej wsparcia kobiet w ciąży powikłanej i rodzin w obliczu urodzenia się dziecka, u którego „zdiagnozowano ciężkie i nieodwracalne upośledzenie albo nieuleczalną chorobę" zagrażającą jego życiu. Program ten Rada Ministrów uchwaliła 20 grudnia 2016 r., a 30 grudnia uchwałę tę, wraz ze 110-stronicowym dokumentem, opublikowano w „Monitorze Polskim”. Uchwała weszła w życie 2 dni później, czyli 1 stycznia 2017 r.

26 Według danych Ministerstwa Rodziny, Pracy i Polityki Społecznej w roku 2018 w środowiskowych domach samopomocy przebywało ponad 5 tys. uczestników przejawiających zaburzenia ze spektrum autyzmu oraz osób z niepełnosprawnością sprzężoną; por. pismo Minister Rodziny, Pracy i Polityki Społecznej z dnia 18 lutego 2019 r. do Rzecznika Praw Obywatelskich, BON.VII.071.1.2019.EG, https://www.rpo.gov.pl/sites/default/ files/Odpowiedz\%20MRPiPS\%20ws\%20wsparcia\%20dla\%20os\%C3\%B3b\%20z\%20autyzmem.pdf [dostęp: 14.07.2020]. 
Osoby z niepełnosprawnością sprzężoną i ze spektrum autyzmu...

\section{Skutki prawne przyjętej regulacji}

Zważywszy na fakt, że nowelizacja art. 51c ustawy o pomocy społecznej miała na celu zwiększenie środków przeznaczanych na osoby z niepełnosprawnością sprzężoną lub ze spektrum autyzmu, zasadna wydaje się w tym miejscu refleksja nad tym, kim powinien być beneficjent tej regulacji. W pierwszej kolejności do tej kategorii podmiotów zaliczyć należałoby osoby z niepełnosprawnością sprzężoną i ze spektrum autyzmu. To właśnie te osoby można zaliczyć do beneficjentów bezpośrednich, którzy w głównej mierze powinni odnieść korzyści z przyjętej regulacji. Jako beneficjentów pośrednich można natomiast potraktować opiekunów tych osób, którzy mogą uzyskać wsparcie polegające na przyjęciu osoby z niepełnosprawnością do dziennego lub całodobowego ośrodka, gdzie uzyska ona kompleksową opiekę edukacyjno-rehabilitacyjną. Bardzo ważne jest przy tym, aby opiekun był przekonany, że wsparcie udzielane osobie z niepełnosprawnością będzie bardzo profesjonalne i w pełni będzie zaspokajać jej potrzeby. Warto zauważyć, że bardzo często rodzice dzieci z niepełnosprawnościami, mimo ogromnego poświęcenia i miłości okazywanej swojemu dziecku, nie są w stanie w pełni zaspokoić jego potrzeb rehabilitacyjnych czy opiekuńczych ${ }^{27}$.

Aby zapewnić takie właśnie profesjonalne wsparcie, konieczne jest oczywiście odpowiednie finasowanie. Warto $\mathrm{w}$ tym miejscu podkreślić, że zgodnie $\mathrm{z}$ art. 18 ust. 1 pkt 3 ustawy o pomocy społecznej w ramach zadań zleconych z zakresu administracji rządowej gmina ma obowiązek organizowania i świadczenia specjalistycznych usług opiekuńczych w miejscu zamieszkania dla osób z zaburzeniami psychicznymi (w tym oczywiście dla osób z niepełnosprawnością sprzężoną i ze spektrum autyzmu ${ }^{28}$ ). Realizacja tego obowiązku polega $\mathrm{w}$ praktyce na zapewnieniu przez gminne ośrodki pomocy społecznej wsparcia społecznego dla osób dotkniętych takimi zaburzeniami. Co szczególnie istotne, usługi te finansowane są $\mathrm{z}$ budżetu państwa. Biorąc to pod uwagę, można mieć obawę, czy środki przekazywane gminom na realizację tego wsparcia $\mathrm{z}$ budżetu będą wystarczające. Jeżeli okaże się, że nie, to w konsekwencji może to oznaczać niedobór kadry specjalistycznej (psychologów, pedagogów, logopedów, pracowników socjalnych), która mogłaby pracować $\mathrm{z}$ takimi osobami w ramach specjalistycznych usług opiekuńczych.

Czy zatem nowelizację art. 51c ustawy o pomocy społecznej można z perspektywy czasu ocenić pozytywnie jako próbę zwiększenia dostępu do specjalistycznych usług opiekuńczych dla osób ze spektrum autyzmu i z niepełnosprawnością sprzężoną? Niestety, można mieć co do tego pewne wątpliwości. Przede wszystkim zgodnie z postanowieniami ustawy właściwy wojewoda może zwiększyć do

27 Por. M. Borski, Publiczne formy wsparcia opiekunów osób z niepełnosprawnościami, Sosnowiec 2018, s. 177.

28 Weryfikacja osób, które kwalifikują się do objęcia ich tą formą wsparcia, ma polegać na potwierdzeniu niepełnosprawności orzeczeniem oraz zaświadczeniem z poradni zdrowia psychicznego. 
$30 \%$ dotację na jednego uczestnika środowiskowego domu samopomocy, ustalaną na uczestników $\mathrm{z}$ niepełnosprawnościami sprzężonymi lub ze spektrum autyzmu, którzy posiadają orzeczenie o znacznym stopniu niepełnosprawności, wraz ze wskazaniem konieczności stałej lub długotrwałej opieki lub pomocy innej osoby w związku ze znacznie ograniczoną możliwością samodzielnej egzystencji. Jest to fakultatywne uprawnienie wojewody, który teoretycznie nie będzie musiał (jeżeli uzna na przykład, że nie dysponuje wystarczającymi środkami finansowymi) zwiększać dotacji nawet przy założeniu, że uczestnikiem ŚDS będzie osoba z niepełnosprawnością sprzężoną lub ze spektrum autyzmu. Niestety, wydaje się, że ustawodawca pozostawił sobie tutaj furtkę na wypadek, gdyby w systemie zwyczajnie zabrakło pieniędzy ${ }^{29}$. Nawet jednak jeżeli dotacja zostanie rzeczywiście zwiększona, to niekoniecznie środki te pozwolą na zapewnienie specjalistycznych usług opiekuńczych dla osób z niepełnosprawnością sprzężoną i ze spektrum autyzmu na odpowiednim poziomie. Przecież terapia tych osób jest wielokrotnie droższa niż na przykład osób z innymi zaburzeniami psychicznymi. Wydaje się zatem, że aby osoby ze spektrum autyzmu i z niepełnosprawnością sprzężoną rzeczywiście częściej i chętniej były przyjmowane do tych placówek - konieczny jest po prostu wzrost kwoty dotacji na jednego uczestnika ŚDS.

Taki wzrost dotacji na razie nie nastąpił. Nie można jednak nie zauważyć pewnych działań podejmowanych przez resort rodziny, pracy i polityki społecznej, mających na celu zwiększenie dostępności ŚDS dla osób z autyzmem i niepełnosprawnością sprzężoną. Przede wszystkim należy zwrócić uwagę na dokonaną zmianę rozporządzenia $\mathrm{w}$ sprawie środowiskowych domów samopomocy. Otóż w nowelizacji z 18 grudnia 2018 r. $^{30}$ określony został minimalny standard dla domów, w których przebywają osoby $\mathrm{z}$ zaburzeniami ze spektrum autyzmu i niepełnosprawnością sprzężoną. W jego ramach wskaźnik zatrudnienia pracowników zespołu wspierająco-aktywizującego określono w wymiarze nie mniejszym niż jeden etat na trzech uczestników. Ponadto do katalogu usług realizowanych przez te domy wprowadzono niezbędną opiekę nad uczestnikami z tego typu zaburzeniami, a także trening umiejętności komunikacyjnych, $\mathrm{w}$ tym $\mathrm{z}$ wykorzystaniem alternatywnych i wspomagających sposobów porozumiewania się - w przypadku osób z problemami w komunikacji werbalnej. Wprowadzono także obowiązek prowadzenia pokoju wyciszeń w odrębnym pomieszczeniu w domach, w których jest więcej niż trzech uczestników z zaburzeniami ze spektrum autyzmu. Według minister rodziny, pracy i polityki społecznej nie ulega wątpliwości, że rozwiązania te podnoszą jakość

29

Zob. M. Borski, Czy zmiany w ustawie o pomocy społecznej wprowadzone ustawą z dnia 22.06.2017 r. o zmianie niektórych ustaw w związku z realizacją programu „Za życiem” realizują założenia programu kompleksowego wsparcia dla rodzin „Za życiem”?, „Przegląd Prawa Publicznego” 2018, nr 3, s. 18.

30 dzenie w sprawie środowiskowych domów samopomocy (Dz.U. z 2018 r. poz. 2411). 
Osoby z niepełnosprawnością sprzężoną i ze spektrum autyzmu...

świadczonych przez ŚDS usług, co pozytywnie wpłynie na funkcjonowanie osób $\mathrm{z}$ autyzmem oraz niepełnosprawnościami sprzężonymi w istniejących już ośrodkach wsparcia. Wydaje się jednak, że podjęte działania to stanowczo zbyt mało. Specyfika zaburzeń osób z niepełnosprawnością ze spektrum autyzmu i z niepełnosprawnością sprzężoną powoduje, że konieczne wydaje się stworzenie specjalnej kategorii ŚDS przeznaczonych dla tych osób. W tym kontekście warto zwrócić uwagę na zmianę rozporządzenia w sprawie środowiskowych domów samopomocy dokonaną 16 maja 2019 r., która weszła w życie 5 czerwca 2019 r. po 14-dniowym vacatio legis ${ }^{31}$. Nowelizacja ta przewiduje możliwość tworzenia nowego typu placówek (typ D), jednak bez dookreślenia szczegółowych standardów funkcjonowania i świadczenia wsparcia dostosowanych do potrzeb osób ze spektrum autyzmu i z niepełnosprawnością sprzężoną. Wydaje się, że przyjęte rozwiązania są bardzo powierzchowne i wymagają doprecyzowania. Bez ich uszczegółowienia może okazać się, że przy permanentnym braku środków słuszna idea stworzenia miejsc dedykowanych dla tej szczególnie potrzebującej kategorii osób z niepełnosprawnościami pozostanie kolejnym słusznym, ale nierealizowanym w praktyce postulatem.

\section{Jak powinno wyglądać wsparcie świadczone przez ŚDS dla osób ze spektrum autyzmu i z niepełnosprawnością sprzężoną?}

De lege ferenda należałoby postulować rozdzielenie placówek dla obu kategorii osób z niepełnosprawnościami poprzez stworzenie odrębnej kategorii ŚDS dla osób z niepełnosprawnością sprzężoną. Wyodrębnienie małych specjalistycznych placówek, oddzielnych dla osób z autyzmem oraz dla osób z niepełnosprawnościami sprzężonymi, wydaje się konieczne, gdyż każda z tych grup osób wymaga innego wsparcia. We wsparciu osób z autyzmem konieczna jest szczególna uwaga i odpowiednie umiejętności terapeutów w zakresie zapobiegania tzw. zachowaniom trudnym. Osoby $z$ autyzmem na skutek stresu, przebywania w większej grupie, nadmiaru bodźców, nadwrażliwości sensorycznej, nieumiejętnego podejścia terapeutów czy trudności z radzeniem sobie $\mathrm{z}$ emocjami przejawiają zachowania dla większości osób (również innych uczestników z niepełnosprawnościami lub terapeutów) stanowiące barierę nie do zaakceptowania. Zachowania te tylko tytułem przykładu mogą obejmować: bicie, kopanie, gryzienie, szczypanie, natrętne dotykanie lub wąchanie innych osób, a nawet samookaleczanie się. Właśnie dlatego środowiska opiekunów osób ze spektrum autyzmu wystąpiły swego czasu z petycją do premiera Mateusza Morawieckiego i minister rodziny, pracy i polityki społecznej Elżbiety Rafalskiej o rozszerzenie sieci środowiskowych domów samopomocy

31 Rozporządzenie Ministra Rodziny, Pracy i Polityki Społecznej z dnia 16 maja 2019 r. zmieniające rozporządzenie w sprawie środowiskowych domów samopomocy (Dz.U. z 2019 r. poz. 967). 
o małe placówki typu D dla nisko funkcjonujących osób z autyzmem i typu E dla osób z niepełnosprawnością sprzężoną oraz niepełnosprawnością intelektualną.

Konieczne wydaje się także (na co wskazują pedagodzy specjalni) ograniczenie liczby uczestników ŚDS dla osób ze spektrum autyzmu do 10, gdyż specyfika autyzmu powoduje, że osoby nim dotknięte nie mogą żyć w dużych domach i nie mogą funkcjonować w dużych grupach - nie są w stanie się zaadaptować do takich warunków. Po ostatniej nowelizacji rozporządzenia ministra rodziny, pracy i polityki społecznej w sprawie środowiskowych domów samopomocy liczba uczestników ŚDS w przypadku, gdy są nimi wyłącznie osoby ze spektrum autyzmu może oscylować w przedziale od 5 aż do 60.

Przyjęte w wyżej wspomnianym rozporządzeniu rozwiązanie, zakładające, że wskaźnik zatrudnienia pracowników zespołu wspierająco-aktywizującego, powinien wynosić nie mniej niż jeden etat na trzech uczestników, także wymaga uściślenia poprzez przyjęcie, że na jednego uczestnika ŚDS ze spektrum autyzmu zawsze musi przypadać jeden pracownik. Trzeba bowiem pamiętać, że osoby z zaburzeniami ze spektrum autyzmu wymagają specjalnego wsparcia i wzmożonej uwagi.

Niezależnie od powyższego kluczową kwestią wydaje się jednak zwiększenie finansowania ŚDS dla osób ze spektrum autyzmu, gdyż wdrożenie nowych rozwiązań spowoduje zwiększenie zadań, a brak realnego finansowania zadania nałożonego na samorządy może hamować rozwój tej formy wsparcia. Jak słusznie zauważył w piśmie do minister rodziny pracy i polityki społecznej rzecznik praw obywatelskich, ŚDS jest to ostatnie ogniwo dziennego wsparcia systemu opieki społecznej, które jest szansą dla osób z niepełnosprawnością na lepsze funkcjonowanie i zapobiega ich izolacji. Nie powinna istnieć sytuacja, gdy osoba $\mathrm{z}$ niepełnosprawnością jest takiego wsparcia pozbawiona. Wydaje się więc zasadne dokonanie kompleksowej, ogólnokrajowej analizy zarówno w aspekcie dostępności środowiskowych domów samopomocy dla wymagających specjalistycznego wsparcia osób ze spektrum autyzmu, jak i oszacowania skali potrzeb ${ }^{32}$.

\section{Próba podsumowania}

Podsumowując, wydaje się, że zwiększenie środków na funkcjonowanie ŚDS, przewidziane w nowelizacji ustawy o pomocy społecznej, a także dokonane w ostatnich latach zmiany w rozporządzeniu dotyczącym środowiskowych domów samopomocy są stanowczo niewystarczające i należy podejmować dalsze działania idące w kierunku rozszerzania oferty ŚDS w stosunku do osób z niepełnosprawnością

Pismo Rzecznika Praw Obywatelskich z dnia 9 kwietnia 2019 r. do Minister Rodziny, Pracy i Polityki Społecznej, III.7065.9.2019.JA, https://www.rpo.gov.pl/sites/default/files/kolejne\%20WG\%20\%C5\%9Brodowiskowe\%20 domy\%20samopomocy\%209\%20kwietnia\%202019.pdf [dostęp: 14.07.2020]. 
Osoby z niepełnosprawnością sprzężoną i ze spektrum autyzmu...

sprzężoną i ze spektrum autyzmu. Konieczność uwzględnienia oczekiwań osób ze spektrum autyzmu i z niepełnosprawnością sprzężoną oraz ich opiekunów wydaje się dostrzegać także minister rodziny pracy i polityki społecznej, która w piśmie do rzecznika praw obywatelskich zauważa, że „Ministerstwo Rodziny Pracy i Polityki Społecznej analizuje uwagi zebrane w związku z przekazaniem projektu, o którym mowa na wstępie do konsultacji społecznych, które są w części zbieżne z uwagami przedstawionymi przez Pana Rzecznika. Dodatkowo w Ministerstwie odbyło się spotkanie z przedstawicielami środowiska osób ze spektrum autyzmu. Podczas spotkania ustalono, że Ministerstwo Rodziny Pracy i Polityki Społecznej ponownie dokona stosownej diagnozy i analizy potrzeb jednostek samorządu terytorialnego oraz ich zainteresowania w zakresie prowadzenia małych środowiskowych domów samopomocy typu D (dla osób ze spektrum autyzmu) i E (dla osób z niepełnosprawnością sprzężoną) odrębnie dla tych grup osób, uwzględniając założenia przedstawione w uwagach zgłoszonych przez środowisko osób ze spektrum autyzmu lub niepełnosprawnościami sprzężonymi”. Czy wskazane wyżej postulaty zostaną uwzględnione i staną się częścią systemu prawa powszechnie obowiązującego, czy też słowa pani minister były tylko próbą odepchnięcia na jakiś czas poważnego problemu - czas pokaże. Obawiam się, że Ministerstwo Rodziny Pracy i Polityki Społecznej nie ma spójnej wizji wsparcia udzielanego osobom ze spektrum autyzmu i z niepełnosprawnością sprzężoną. Pokazuje to przyjęty w ubiegłym roku do realizacji przez to ministerstwo program pod nazwą „Centra Opiekuńczo-Mieszkalne”33. W zapowiedziach ministerstwo przedstawiało go jako program przeznaczony dla osób dorosłych ze spektrum autyzmu i z niepełnosprawnością sprzężoną ${ }^{34}$. Warto zauważyć, że jako beneficjentów tego programu wskazano wszystkie dorosłe osoby ze znacznym lub umiarkowanym stopniem niepełnosprawności. Obawiam się, że przy ograniczonej ilości środków z programu znowu skorzysta stosunkowo niewiele „najbardziej problematycznych” osób z niepełnosprawnością ze spektrum autyzmu. Niezależnie od tego warto dodać, że tworzenie odrębnych ŚDS dla osób ze spektrum autyzmu i osób z niepełnosprawnością sprzężoną jest kontestowane przez część środowiska osób z niepełnosprawnościami. Twierdzą oni, że tego typu rozwiązania nie sprzyjają integracji, wręcz przeciwnie - mogą prowadzić do gettoizacji. Tymczasem osoby z niepełnosprawnościami powinny żyć w otoczeniu osób pełnosprawnych i w ten sposób współtworzyć realne społeczeństwo, będące sumą osób pełno- i niepełnospraw-

33 Zob. Centra opiekuńczo-mieszkalne - edycja 2019, Dolnośląski Urząd Wojewódzki we Wrocławiu, https:// www.duw.pl/pl/urzad/programy/fundusz-solidarnosciowy/centra-opiekunczo-miesz/15535, Centra-opiekunczo-mieszkalne-edycja-2019.html [dostęp: 14.07.2020].

Por. Ogłoszenie o planie działania na rzecz wsparcia osób niepełnosprawnych na 2020 r., Biuro Pełnomocnika Rządu ds. Osób Niepełnosprawnych, 29.11.2019, http://www.niepelnosprawni.gov.pl/art,944,ogloszenia-o-planie-wsparcia-na-2020-rok [dostęp: 14.07.2020]. 
nych. Separowanie osób z niepełnosprawnością sprzężoną i osób ze spektrum autyzmu nie sprzyja takiemu włączającemu podejściu.

Niezależnie od powyższego polski prawodawca nie może ignorować faktu, że osoby ze spektrum autyzmu są bardziej zagrożone dyskryminacją niż osoby dotknięte innymi niepełnosprawnościami. Konwencja ONZ o prawach osób niepełnosprawnych ${ }^{35} \mathrm{w}$ art. 2 definiuje dyskryminację ze względu na niepełnosprawność jako wszelkie formy różnicowania, wykluczania lub ograniczania ze względu na niepełnosprawność, których celem lub wynikiem jest utrudnienie lub uniemożliwienie uznania, korzystania lub egzekwowania wszelkich praw człowieka i fundamentalnych swobód na równych zasadach $\mathrm{z}$ innymi obywatelami w sferze politycznej, gospodarczej, społecznej, kulturowej, obywatelskiej i innej. Co szczególnie ważne, definicja ta obejmuje także odmowę racjonalnego dostosowania środowiska do szczególnych potrzeb osób z niepełnosprawnością. Również Karta Praw Osób z Autyzmem ${ }^{36}$ nie tylko zakazuje dyskryminacji osób z autyzmem, ale zobowiązuje do uwzględniania specyfiki niepełnosprawności i specyficznych potrzeb tej grupy osób we wszystkich rozwiązaniach regulujących system wsparcia.

Ocena istniejących regulacji dotyczących wsparcia udzielanego przez państwo tej bardzo potrzebującej grupie osób z niepełnosprawnościami nie jest niestety zadowalająca. O ile pozytywnie ocenić można konkretne regulacje normatywne dotyczące rozwiązań organizacyjno-prawnych związanych z utworzeniem ŚDS, o tyle zasadniczym problemem wydaje się kwestia ich finansowania. Przede wszystkim niewystarczające są środki przekazywane gminom z budżetu państwa, co w konsekwencji powoduje niedobór kadry specjalistycznej (psychologów, pedagogów, logopedów, pracowników socjalnych), która mogłaby pracować $\mathrm{z}$ takimi osobami w ramach specjalistycznych usług opiekuńczych. Aby więc środowiskowe domy samopomocy, w których świadczone są te usługi, mogły działać w sposób prawidłowy, konieczny jest po prostu wzrost kwoty dotacji na jednego uczestnika ŚDS. Jest to warunek sine qua non zapewnienia odpowiedniego wsparcia osobom z zaburzeniami psychicznymi i ich opiekunom. Nie ulega bowiem wątpliwości, że bez rehabilitacji, terapii i możliwości rozwoju osoby te skazane są na regres.

35 Konwencja ONZ o prawach osób z niepełnosprawnościami, sporządzona w Nowym Jorku dnia 13 grudnia 2006 r. (Dz.U. z 2012 r. poz. 1169).

36 Uchwała Sejmu RP z dnia 12 lipca 2013 r. Karta Praw Osób z Autyzmem (M.P. z 2013 r. poz. 682). 


\section{Akty prawne}

Konwencja ONZ o prawach osób z niepełnosprawnościami, sporządzona w Nowym Jorku dnia 13 grudnia 2006 r. (Dz.U. z 2012 r. poz. 1169).

Ustawa z dnia 7 września 1991 r. o systemie oświaty (tekst jedn. Dz.U. z 2018 r. poz. 1457 z późn. zm.).

Ustawa z dnia 19 sierpnia 1994 r. o ochronie zdrowia psychicznego (tekst jedn. Dz.U. z 2018 r. poz. 1878).

Ustawa z dnia 12 marca 2004 r. o pomocy społecznej (tekst jedn. Dz.U. z 2018 r. poz. 1508 z późn. zm.).

Ustawa z dnia 14 grudnia 2016 r. Prawo oświatowe (tekst jedn. Dz.U. z 2018 r. poz. 996 z późn. zm.).

Ustawa z dnia 22 czerwca 2017 r. o zmianie niektórych ustaw w związku z realizacją programu „Za życiem” (Dz.U. z 2017 r. poz. 1292).

Rozporządzenie Ministra Rodziny, Pracy i Polityki Społecznej z dnia 18 grudnia 2018 r. zmieniające rozporządzenie w sprawie środowiskowych domów samopomocy (Dz.U. z 2018 r. poz. 2411).

Rozporządzenie Ministra rodziny, pracy i polityki społecznej z dnia 16 maja 2019 r. zmieniające rozporządzenie $\mathrm{w}$ sprawie środowiskowych domów samopomocy (Dz.U. z 2019 r. poz. 967).

Uchwała Sejmu RP z dnia 12 lipca 2013 r. Karta Praw Osób z Autyzmem (M.P. z 2013 r. poz. 682).

\section{Literatura}

Baron-Cohen S., Bolton S., Autyzm. Fakty, Kraków 1999.

Błeszyński J., Rodzina jako środowisko osób z autyzmem. Aspekt wychowawczo-terapeutyczny, Toruń 2005.

Borski M., Czy zmiany $w$ ustawie o pomocy społecznej wprowadzone ustawa $z$ dnia 22.06.2017 r. o zmianie niektórych ustaw $w$ związku $z$ realizacja programu „Za $\dot{z} y$ ciem” realizuja założenia programu kompleksowego wsparcia dla rodzin „Za $\dot{z} y$ ciem”?, „Przegląd Prawa Publicznego” 2018, nr 3, s. 10-27.

Borski M., Publiczne formy wsparcia opiekunów osób z niepełnosprawnościami, Sosnowiec 2018.

Doroszewska J., Pedagogika specjalna, t. 1-2, Wrocław-Warszawa-Kraków-Gdańsk-Łódź 1989.

Majewski T., Edukacja i rehabilitacja osób głuchoniewidomych, Warszawa 1995.

Pisula E., Rodzice dzieci z autyzmem, Warszawa 2012.

Twardowski A., Wychowanie dzieci o niepełnosprawności sprzężonej, [w:] Dziecko niepełnosprawne w rodzinie, red. I. Obuchowska, Warszawa 2008, s. 533-542.

Vašek Š., Stankowski A., Zarys pedagogiki specjalnej, Katowice 2006. 
Wiącek G., Problem definiowania niepetnosprawności sprzężonej, [w:] Sytuacja i możliwości pomocy dla osób z rzadkimi i sprzężonymi ograniczeniami sprawności, red. A. Brzezińska, R. Kaczan, K. Smoczyńska, Warszawa 2010, s. 71-86.

\section{Źródła internetowe}

Centra opiekuńczo-mieszkalne - edycja 2019, Dolnośląski Urząd Wojewódzki we Wrocławiu, https://www.duw.pl/pl/urzad/programy/fundusz-solidarnosciowy/centra-opiekunczo-miesz/15535,Centra-opiekunczo-mieszkalne-edycja-2019.html.

http://www.sds24.pl/niepelnosprawnosc-sprzezona.

Ogłoszenie o planie wsparcia na 2020 rok, Biuro Pełnomocnika Rządu ds. Osób Niepełnosprawnych, 29.11.2019, http://www.niepelnosprawni.gov.pl/art,944,ogloszenia-o-planie-wsparcia-na-2020-rok.

Ogólnopolski Spis Autyzmu. Sytuacja młodzieży i dorosłych z autyzmem w Polsce, red. M. Płatos, Warszawa 2016, www.spisautyzmu.pl.

Pismo Minister Rodziny, Pracy i Polityki Społecznej z dnia 18 lutego 2019 r. do Rzecznika Praw Obywatelskich, BON.VII.071.1.2019.EG, https://www.rpo.gov.pl/sites/default/files/Odpowiedz\%20MRPiPS\%20ws\%20wsparcia\%20dla\%20 os\%C3\%B3b\%20z\%20autyzmem.pdf.

Pismo Rzecznika Praw Obywatelskich z dnia 9 kwietnia 2019 r. do Minister Rodziny, Pracy i Polityki Społecznej, III.7065.9.2019.JA, https://www.rpo.gov.pl/sites/default/ files/kolejne\%20WG\%20\%C5\%9Brodowiskowe\%20domy\%20samopomocy\%20 9\%20kwietnia\%202019.pdf.

Społeczny obraz autyzmu, komunikat z badań CBOS nr 47/2015, Warszawa 2015, https:// www.cbos.pl/SPISKOM.POL/2015/K_047_15.PDF.

Stowarzyszenie Pomocy Osobom Autystycznym „Dalej Razem”, http://www.autyzm.zgora. $\mathrm{pl} / \mathrm{pl} / \mathrm{id} .10004$. 